\title{
ANGIOTENSIN CONVERTING ENZYME ACTIVITY AND ANGIOTENSIN CONVERTING ENZYME GENE POLYMORHISM IN NEONATAL TRANSIENT TACYPNEA AND RESPIRATUAR DISTRESS SYNDROME
}

\author{
M. Satar ${ }^{1}$, E. Taşkın ${ }^{1}$, F. Özlü ${ }^{1}$, A. Tuli ${ }^{2}$, K. Özcan ${ }^{1}$, H.Y. Yapıcıoglu ${ }^{1}$

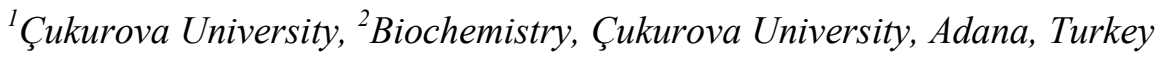

Transient Tacypnea of Neonate (TTN) and Respiratory Distress Syndrome (RDS) are the most common causes of respiratory distress in early neonatal period. The pathogenesis of TTN is still not well understood and is thought to be due to inadequate clearance of fetal lung fluid. In last decades, the evidence of the role of renin-aldostrene-angiotensin in acute lung injury is increasing.

In this study the relation between angiotensin converting enzyme (ACE) I/D polymorphism and ACE activity and TTN and RDS is studied.

ACE I/D polymorphism and ACE activity in 19 neonates with TTN, 20 with RDS and 21 control neonates were evaluated.

Result: DD polymorphism in 26 neonates (43,3\%), ID polymorphism in 19 neonates $(31,7 \%)$ and II polymorphism in 15 neonates $(25 \%)$ were demonstrated. Serum ACE activity with DD polymorphism was $43,5 \pm 1,8(40-46) \mathrm{U} / \mathrm{L}$, in ID polymorphism was $31,5 \pm 2,3(28-36) \mathrm{U} / \mathrm{L}$ and II polymorphism was $22,1 \pm 2,1$ (1946) U/L. DD allele were not significantly different between control and TTN neonates. DD allele was not significantly different between RDS and control neonates.

These results don't support the relation between ACE I/D polymorphism and ACE activity in TTN and RDS. 